\title{
Voicing The Silences: Women In Contemporary Pakistani Fiction In English
}

\author{
Sadaf Mehmood \\ Department of English \\ International Islamic University Islamabad
}

\begin{abstract}
Indigenous women of Pakistan have long been struggling with the patriarchal norms. Categorization of their existence in the conventional oppressions connotes diversified victimization. Grappling with such assorted repressions and articulating the subsequent silences, women writers of Pakistan and the social activists are incessantly engaged to empower women from societal peripheries. The selected fiction exposes how the indigenous woman is controlled and exploited on the name of religio-cultural rhetoric. The present article outlines the historical developments in changing the social positioning of women after independence by highlighting the urgency of raising women consciousness in the academic sphere to form an alliance for collective identity. This article evaluates Ice Candy Man (1988), My Feudal Lord (1994) and Trespassing (2003) to explore the changing images of indigenous Pakistani women after partition. It aims to highlight the struggle and resistance of female characters against the patriarchal propriety of Pakistani society. The study is significant to highlight the struggles of women writers to articulate the silences of assorted exploitation buried under the hegemony of socio-historical discourses. The study concludes that through female characterization the women writers organize specific academic movement of awakening that provides situational analysis to relate with the turbulences of the fictional world to correspond the real challenges.
\end{abstract}

Keywords: Indigenous Women, Pakistani Fiction, Patriarchy, Exploitation.

\section{تمبه}

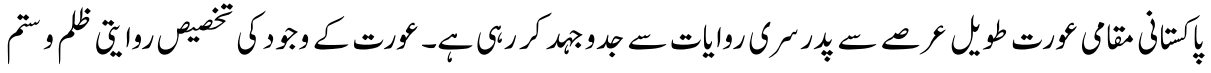

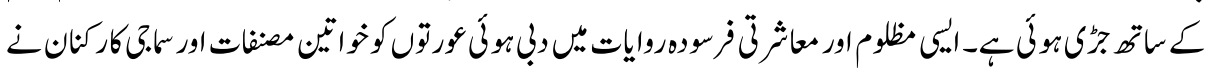

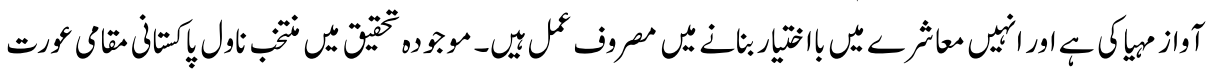

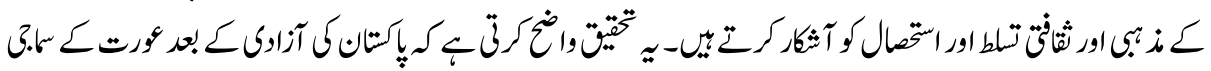

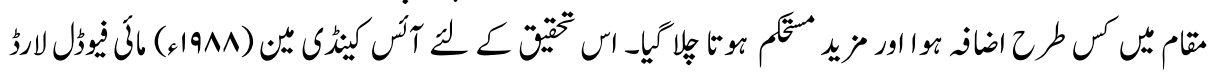

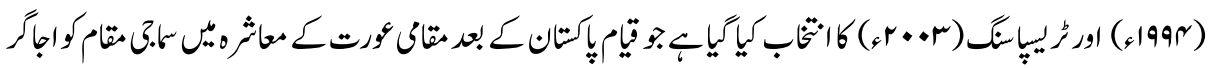

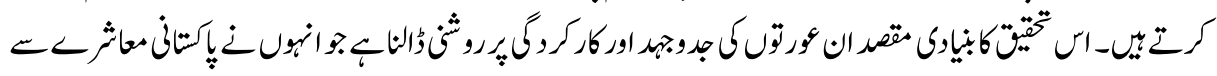

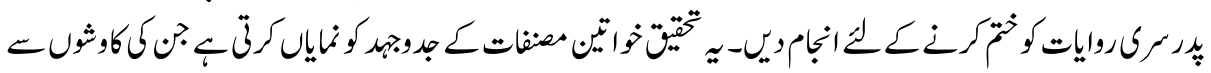




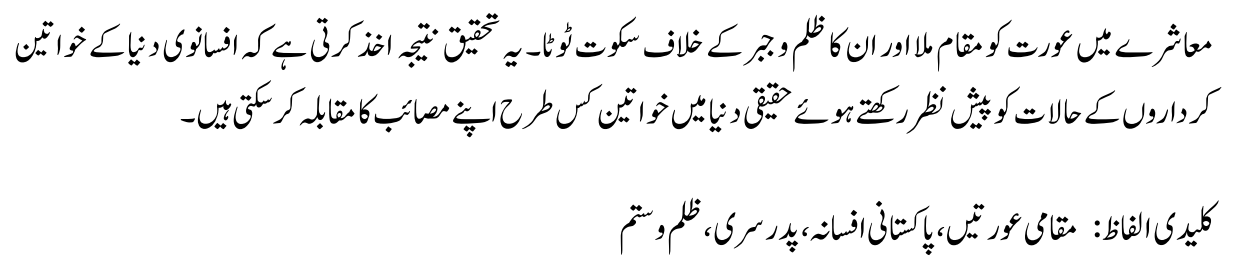

\section{Introduction}

The year 1947 gave independence to Muslim community of colonized Sub-continent. This independence liberated the Muslim community to practice their religion freely in an Islamic state of Pakistan that would be idealized at socio-political level. Though, this slogan of idealism had liberated collective Muslim community from geo-political scenario of colonization. The new state regulated its socio-legal dynamics by confining public sphere for men and private ebb for women. Social exclusion of women organized different women activists to stand for their empowerment. Begum Shaista Ikram Ullah and Begum Jahan Ara Shahnawaz are prominent names to provide legal protection to indigenous women of Pakistan through their successful enactment of Muslim Personal Law of Shariah according to which "women were granted the right to inherit property, including agricultural land" (Shami, 2010, p. 142).

The historical review of the movement of Pakistani woman towards her emancipation gave her a commendable status within the society but it is ironical that the implications of these legal developments are remained only in the legal documents. The woman of Pakistan is still battling with her existence in a patriarchal state. The women are liberated to get education and earn a better living style but she also has to play her domestic role wherein she is obedient daughter, submissive wife and devoted mother. When they try to break the domestic fence and move to the world outside they do not receive any available opportunities to be identified as independent beings. They need to struggle for opportunities that will not regard them dignity and honour they have to lean towards their independency by negotiating with patriarchal conventions.

Along with the legal emancipation, women writers are also struggling to articulate the victimization of women through socio-cultural and religious codifications of subservience. The historical perspective of Women's movements to empowerment lists the resistance by the women activists (APWA, UFWR, WAF) with the consequent result in legal reformations to emancipate and protect women which sheds light on the collective interests of women. Pakistani fiction in English aims to organize socio-literary alliance against the dominant structures of women repression. This alliance demonstrates Pakistani women's intelligence to understand and contribute decisively in policy frameworks to provide alternative solutions against the untold conundrum. Nonetheless, the patriarchal constructions of Pakistani society in feudal, political and tribal infrastructures enforce and insist on the subservient, submissive and silenced attitude of 
women. The present study, based on the works of Pakistani women writers Bapsi Sidhwa, Tehmina Durrani and Uzma Aslam Khan, highlights the resistance and agency of female characters; who experience social oppression with all its intricate entirety. Pakistani fiction is rich in its exploration of female character and its diversified societal experience by infixing women in dramatic analogies in order to organize the nature of their resistance. Zia Ahmed (2009) emphasizes that literature plays vital role in representing the fluctuation in the functioning of society; in this context, the representation of women in literature denotes crucial understanding of the social standing of women in a particular society (Ahmed, 2009, p.90). Literary representation of Pakistani women in English fiction provides an alternative perspective of analyzing the agency of indigenous women who are struggling with diverse patriarchal challenges in the course of development of the country after independence. Pakistani English fiction specifically provides "the unity of sisterhood across patriarchal structures of family, nation, race and creed" which is a "familiar theme in women's writing worldwide" (Shamsie, 2005, p. xiv).

The selected fiction aims to explore the changing images of indigenous Pakistani women after partition. Ice Candy Man (1988) unravels the turmoil of partition that relentlessly endeavored women as easy prey to be dislocated and silenced. Sidhwa unleashes the emotionally, psychologically and physically shattered women whose narratives are after decades of independence remained unheard and untold. My Feudal Lord (1994) by Tehmina Durrani is reflects the dismal plight of women under the tyranny of feudalism. The socio-economic stability of Durrani does not guarantee her happiness. Her autobiographical fiction boldly exposes the predicaments of married women. She presents her transformation from docility to agency because of the interminable exploitation of her womanhood on the name of marriage which is legalized through religio-cultural discourses. Trespassing (2003) highlights the struggles of female characters against the patriarchal conventions of Pakistani society. Uzma Aslam Khan deconstructs the images of women in Pakistani society where their sexuality and loyalty are merely attributed with their husbands. The postmodern women of Pakistan are fearlessly independent in private and public vicinities to dismantle the constructed frames patriarchy in Pakistani society. Categorization of their existence in the conventional oppressions connotes diversified victimization. Social activism is continuously striving to raise consciousness of women and empower them in the society. The women writers of Pakistan also build an alliance with social activism by giving voice to the oppressions through round female characterization. This study is significant to highlight the struggles of women writers to articulate the silences of women who experience assorted exploitation through the hegemony of sociohistorical discourses. However, these victimized women are aware of their rights but do not have affable milieu to claim them. This research probes the role of Pakistani fiction by women to create awareness against the hegemonic dynamics of patriarchy with the representation of round female characters who do not have any identity in the beginning but by the end they acquire their agency and individualism. 


\section{Indigenous Women of Pakistan: A Review of Literature}

Barbarity of colonization and vehemence of partition produced prodigious oeuvres in English language to manifest national character of independent individuals in newly born country of Pakistan. Muneeza Shamsie argues that the choice of writing in English language is an attempt "to write from extreme edges of both English and Pakistani literature" (Shamsie, 2006, p. xiv). While renouncing Anita Desai's claims of considering Pakistani literature as an echo of Indian literature, Cara Cilano contends that the tradition of writing in English is primarily to bring the Pakistani literature out of the shades of Indian literature and "challenge the narrowness of critical reception of English language literature both within Pakistan and beyond" (Cilano, 2009, p. 185). Alamgir Hashmi reinstates that this medium is not merely a manifestation of "Pakistani idiom" but also of "Pakistaniness" (Hashmi, 1990). Tariq Rahman (1991) states that the Pakistani writing unanimously agreed with the "prescriptive dictum that their work must have an extra literary purpose, namely to "serve society" (qtd. in Shamsie, 2006, p. xi). This literary servitude not merely commemorates the rich historical rituals and traditions but also through articulating the social discriminations that cast exclusion on the basis of caste, class or gender. English literariness of Pakistani writings opened new vistas for articulation of Pakistaniness to dismantle the colonial stereotypes of uncouthness and oppression. Deriving from colonial past, it renders retaliation against oppressions whether imperial, social, political or global. It traverses from Pakistani idiom to accentuate the social unrest and disequilibrium by providing stereoscopic explorations of "duality and diversity" (Shamsie, 2011) in time and space. Writing in English language to demonstrate Pakistani idiom also reiterates the deconstruction of hegemonic lines in the societal infrastructure. The social standing of indigenous Pakistani woman is one of the recurring and overarching concerns of literary oeuvres since the existence of Pakistan.

The Heart Divided (1948) by Mumtaz Shah Nawaz is the first novel written by a woman on the theme of partition which is "permeated by a strong consciousness of herself as an educated Muslim woman and political activist, welding both the personal and the public" (Shamsie, 2006, p.xi). The novel adumbrates women experiences of partition and post partition as dispossessed and domesticated figures who are alienated from their religious and national freedom for which they eagerly struggle in pre-partition. The literary characterization serves as an efficacy of social praxis that establishes connection with readers to articulate the lurking silences of socio-political catalogues of women issues and resolutions. While contextualizing feminist tabulations in postcolonial framework Young (2005) puts it:

Postcolonial feminism is certainly concerned to analyze the nervous conditions of being a woman in a post colonial environment, whether in the social oppression of the post colony or the metropolis. Its concern is not in the first place with individual problems but with those that affect the whole communities (Young, 2005, p. 115). 
Pakistani fiction gives voice to the collective silence of women through ongoing social urgency of women activism. The social along with literary articulations enhanced the indigenous form of feminism which pertains its sublimity in time and space. By theorizing patriarchal bargains, Kandiyoti (1988) explains the strategic approach of disempowered women to maximize their opportunities to independent life. She contemplates over the complex existence of women in "patriarchal oppression on one hand and to convey the complex positioning of women with respect to power/disempowerment on the other" (Sa'ar, 2005, p. 681). While negotiating with the patriarchal constraints Pakistani women vacillates between the dividing lines of public and the private sphere. The journey of negotiations and bargains traversed from early decades of pre-partition to unite the domesticated women and persuade them for their mutual consensus over gaining a piece of land where they can celebrate their freedom and empowerment. Struggles for freedom encouraged women's participation in public and political sphere to expand the movement effectively as Anjali Bhardwaj Datta (2006) notes, "Partition pushed women into fashioning new survival strategies and opened up new avenues of education, training and employment for them...as boundaries between private and public shifted back and forth to accommodate this reorganisation" (Datta, 2006, p.2229). However, the existence of Pakistan could not promise freedom to the women and they were sent back to their private spheres. The nascent political administration of newly built nation ventured different democratic and military leadership to define the socio-legal conditions for its citizens particularly for women. The wavering political stability instigated women's activism to struggle for their emancipation in the neocolonial era whereby they experience double marginalization. Women established different platforms to organize their struggles in which All Pakistan Women Association (APWA) lead by Begum Raana Liaqat Ali, played a major role concerning with the health, education and family laws (Naz, 2013). The second marriage of Prime Minister Mohammad Ali Bogra in 1955 instigated United Front for Women's Rights (UFWR) under the supervision of Begum Shahnawaz Jahan Ara to investigate, along with APWA, the existing laws of marriage, divorce, dower, polygamy and custody of children according to the dictates of Islam (Zia, 2010). The legal reforms concerning these issues were proposed in Ayub Khan's regime wherein women were given their basic rights. This Family Law Ordinance regulated the right of divorce for women, discouraged polygamy and administered marriage registration. These clauses appeared to be a ray of hope for the women activists' organizations (Naz, 2013). The constitution of 1962 apparently has not placed any limitations but when Ayub Khan contested Fatima Ali Jinnah in 1964 elections he could not practically set the example of women's emancipation instead he obtained fatwa against the right of woman to acquire highest official status in the society (The Constitution of Pakistan, 1956 Article, 17 (1)). Farida Shaheed (1991) frames the obstruction of female intrusion in the public and political life through "selective implementation of Islam" that has been responsible for the "entrenchment of an all pervasive patriarchal system of inequality and subjugation" 
(Shaheed, 1991, p.140). In late sixties Pakistan People's Party (PPP) emerged under the leadership of Zulfiqar Ali Bhutto who raised slogans in the favor of laborers, workers and women with an emphasis on equal rights for women and 'universal adult sufferage'(The Constitution of Pakistan, 1956 Article, 22 (2)). The emergence of PPP in such a paradoxical state of Ayub's period was welcomed by the women activists with an expectation for their equal legal status in the society. Bhutto's success in 1971's elections gave women a space to revise the favorable constitutional policies in the act of 1973. The distinctive features of this constitution with special reference to women were:

1. All citizens are equal and are entitled to equal protection of law;

2. There should be no discrimination on the basis of sex alone, and

3. Nothing shall prevent the state from making any special provision for the protection of women and children.

(The Constitution of Pakistan, 1956, Article, 44 (2) \& 77 (2))

The martial law imposed by General Zia-Ul-Haq over Bhutto's reign was taken as the leaning period for women organizations. The women were sent back to the domestic walls with a revival of Islamization within the state. Shamsie (2006) notes that the Zia's Islamization in particular "used to victimize the weakest and the most vulnerable women and minorities" (Shamsie, 2006, p.xiii). While examining the legal regulations of Zia's period, Hussain Haqqani also notes the exclusion of women from public life under the aegis of religion: "Clerics who supported these laws argued that women were emotional and irritable, with inferior faculties of reason and memory and that courts ought to discount their testimony as well as that of the blind, handicapped, lunatics, and children" (Haqqani, 2005, p.144). After the death of Zia Pakistani political system enacted 1973's constitution which gradually amends its various sections and phrases to effectively emancipate the women in public and domestic spheres, however Shamsie (2006) contemplates over the despondence of Pakistani women who experience brutal patriarchy in the feudal and tribal premises: "As lawlessness spread, ancient tribal customs were confused with religion, the killing of women in the name of honour increased, and a parallel system of justice, village 'jirga' ensured further victimization" (Shamsie, 2006, p. xix). The evolving political administration and the strong hold of feudal and tribal systems, in the frame of religion, illustrate Pakistani socio-cultural sphere as patriarchal (Gardezi, 2008). The indigenous women of Pakistan, therefore, experience diversified patriarchy according to different time and space. This diversity contributes in making the image of Pakistani women as Khawar Mumtaz and Farida Shaheed (1987) in their book Women of Pakistan: Two Steps Forward, One Step Back notes:

Depending on her geographical location, a Pakistani woman can find herself in a tribal, urban and rural environment. She can be a highly qualified and self-confident professional or a self-effacing peasant toiling alongside her men folk; she can lead a highly cloistered life...or she can be a central figure of authority in the limited circles of 
influential women. The Pakistani woman then is a myriad creature for whom a single image does not suffice. To talk of Pakistani women is in fact to talk of groups of women, of clusters of similarity in a disparate reality (Mumtaz and Shaheed, 1987, p.21).

Mumtaz and Shaheed gauge the tools of oppression and exploitation of indigenous women of Pakistan according to their geographic, cultural and linguistic associations by outlining the women activism. These social movements also became literary to retaliate against the oppressions of women. Enormous fictional corpus is dedicated to voicing the diversified exploitation of women after independence and to expand the social activism through plotting the lives of indigenous women in diversified frames of oppression. These writings devotedly raise consciousness by disclosing how female characters demonstrate their agency against the patriarchal infrastructure. English fiction not merely articulate the exploitation of indigenous women settled in the locality of Pakistan while struggling with social, cultural and economic differences but also highlights the troubles of Pakistani women settled across borders by infixing their existence between the lines of home and abroad. Shamsie (2006) encapsulates the women writers' concerns for choosing English language to challenge "the stereotypes imposed on them, as women and as writers, by the patriarchal culture of countries both in the diaspora and in Pakistan" (Shamsie, 2006, p. xiv). Indigenous Pakistani woman in the English fiction is caught up between the stereotypical representations of religious, tradition and cultural boundaries that unleash their intricate existence. To articulate these intricacies and dismantling of stereotypical constructions, Gayatri C. Spivak suggests inevitability of aesthetic representation. Spivak asserts the diverse and heterogeneous feminist urgency in third world feminism by abandoning the monolithic feminism of the First World, as:

Between patriarchy and imperialism, subject-constitution and object formation, the figure of the woman disappears, not into pristine nothingness, but into a violent shuttling that is the displaced figuration of the "third-world-woman" caught between tradition and modernization, culturalism and development (Spivak, 1999, p.304).

Chandra Talpade Mohanty (2003) examines the feminist narratives of the West with reference to the representation of Third World women and contends:

Discursively colonise the material and historical heterogeneities of the lives of women in the Third World, thereby producing/representing a composite, singular "Third World woman" - an image which appears arbitrarily constructed but nevertheless carries with it the authorizing signature of Western humanist discourse (Mohanty, 2003, p.19).

The female characters dismantle the constructed stereotypes against the third-world Muslim women by framing their oppressions as social and cultural; that are reinforced through selective and thus incoherent religious references. The social activism and the 
literary representations define and defend their religious identities that cast their exclusion or inclusion in mainstream society. The modality common between these two separate academic and social oriented struggles is the manifestation of women's creation of their space in uneven socio-legal spheres of the gendered society. As Pandey elucidates the role of feminism in literature as:

Feminism in literature refers to a mode that approaches a text with foremost concern for the nature of female experience in it. The fictional experience of characters, the rational, intuitional or imaginative capacity of an author, the experience implicit in language of structure that interrogates the cultural prescriptions, that subordinate and trivialize women and treat them as inferiors are the primary concerns of female fiction writers from feminist perspective (Pandey, 2003, p. 1) .

The literature emphasize that the indigenous women of Pakistan is still exploited and discriminated on the basis of her sexuality. Though, she can access the courts and raise her voice but on her way back to courts her family will suffer the consequences of her bold step. The literary works expose different visions of female characters and different tactics to make their existence possible in a society wherein she is merely associated with her physical appearance. Her identity is her body but the man is known qualified individual with all dignity and honour.

\section{Research Methodology}

This research is a qualitative and analytical study in which close textual analysis of Ice Candy Man Bapsi Sidhwa (1988), My Feudal Lord by Tehmina Durrani (1994) and Trespassing by Uzma Aslam Khan (2003) is carried out in order to explore the changing images of indigenous Pakistani women after partition. The history of Pakistan unfolds different stretches of activists' movements that made the present woman assert her individuality in a patriarchal society. The present study at first documents the history of feminist movement in Pakistan at political, social and legal level that aimed to emancipate women collectively, then, focuses on the women living in literary world of Pakistan by facing the patriarchal hardships as individuals. In the light of tracing the journey of Pakistani women from collective to individual identity the present study attempts to seek the answer of following research questions:

1. How the indigenous woman is controlled and exploited on the name of religiocultural rhetoric?

2. How female characters assert their agency and traverse from docility to resistance by challenging the patriarchal infrastructure?

\section{Articulation of the Unheard and Untold}

Bapsi Sidhwa pens the apocalyptic devastation of partition in her debut novel Ice Candy Man. Sidhwa reconstructs the history of partition through highlighting the exploitation of 
women in the tragic riots of the partition. The victimized women devoid of their religious or ethnic differences were ferociously molested, abducted and raped during their dislocations and resettlements on newly established boundaries. Urvashi Butalia (1998) states that "about 75,000 women are thought to have been abducted and raped by men of religions different than their own, and indeed sometimes by men of their own religion" (Bulatia, 1998, p.3). Rabia Umar Ali (2009) probes the historical silence of partition with specific reference to Muslim women is rigid because of the "patriarchal constraints" and the religious restrictions which "hardly find a place in collective memory and must remain at the margins, untold and unsaid" (2009, p. 428). Recollection of this catastrophe is merely possible through fictional frames of history to articulate the bitter tales of sacrifices and violence by challenging the demographic details of political history:

The political flow of events catalogued and recorded to the minutest details are supplemented by the experiences of all those unfortunate women, who committed mass suicide by drowning themselves in wells to escape disgrace, or the young girls who were raped in the towns and villages of Punjab, or all those helpless souls who unwillingly converted to another religion and were never accepted back (Ali, 2009, p. 435).

The excruciating agony that remains inconspicuous in the political history needs to be displayed through aesthetic appeal. Sidhwa's contribution in voicing the miseries of women's partition experiences which collapsed their emotional, psychological and physical existence by some exoteric political decisions. While dividing the plot development in three time periods; pre-partition partition and post-partition, Sidhwa demonstrates how domesticated women became the tools of exploitation during the trauma of partition (Didur, 1998). The women in Pir Pindo whom Lenny observes as completely negligent about the presence of Akalis in the village are busy in their domestic chores. Their primary concerns are qualifying their domestic oriented affairs; the political decisions are associated to men folk without realizing that it will shatter their souls and ruin their vulnerable existence. As Lenny relates this political tumult as exoteric that will be impervious in her vicinity; "Gandhi, or Nehru or Jinnah, but I'm fed up of hearing about them. Mother, Father and their friends are always saying: Gandhi said this, Nehru said that. Gandhi did this, Jinnah said that. What's the point of talking so much about people we don't know" (Sidhwa, 1988, p. 29). The ordinary people who assumed this political talk would not influence their lives were devastated by its horrific ends. Symbols of family prestige, the innocent women were brutally raped and disfigured by the opponents to announce their victory as Deepika Bahri (1999) notes:

The punishment of the female body becomes an attack on the opponent through an elaborate inscription of women as the patrimonial body of state and religion. The fetishized status of woman as metonymic totem of national, cultural, religio-communal being and the emphasis on her purity are key elements in this gynocentered assault on the enemy (Bahri, 1999, p.222). 
Sidhwa portrays the catastrophic vehemence of partition being cast on female body. The characterization of Papoo, Mini Anti, Hamida and Noni chachi epitomize their inability to change their living conditions during the religio-socio-cultural dilemmas however, Ayah appears to be the characters who challenge the impositions of the patriarchal constraints. Adorable Ayah in her circle of Muslim and non-Muslim admirers, has an ecstasy of sexual flirtations beyond tiresome engagements in domestic sphere by roaming in the streets and commenting over the current political milieu. Ayah remains assertive in the company of her admirers and allows access to only those whom she desires. Her presence in the circle of admirers bestows her numerous gifts and favours that exposits her self-confidence. Her carefree life was suddenly haunted by the uncertainty and insecurity of the partition havoc. Before partition Ice Candy Man always used to adore Ayah's chocolate brown beauty and seems to remain around her, "where Ayah is, is Ice Candy Man....he has as many eyes, and they follow us" (Sidhwa, 1988, p. 121). However, as the partition takes place, Ayah's beauty could not stand the hatred of Ice Candy Man as a Muslim whose sisters are abducted from the train in Gurdaspur:

The last thing I noticed was Ayah, her mouth slack and piteously gaping, her disheveled hair flying into her kidnappers' faces, staring at us as if she wanted to leave behind her wide-open and terrified eyes (Sidhwa, 1988, p. 184).

Ayah who is innocent and regretful over the tragedy of Gurdaspur is treated as an object to be ravaged and molested as the remnants of enemies. Ayah's rediscovery as dancing girl represents legions of Hindu, Muslim and Sikh women who are victims of partition chaos. Ayah's insistence on leaving for her country demonstrates her agency by rejecting the bestowed dignity of her husband; Ice Candy Man who pledges to be loyal with her but she could not forget the ignominious humiliation he cast over her. She prefers her return over the forceful marital relationship though Sidhwa does not guarantee her probable reception but the mortification etched on her soul directs her to take this decision though her destined country accept her or not. Sidhwa's morose articulation of women's oppression during partition is terribly horrid; particularly in Pir Pindo, she represents women's engagement in domestic chores and their disconnected lives from the political talk of partition. Partition event which was a political affair eventually captivated each woman in Muslim dwellings in its devastation and desolation by treating women as the greatest object of exploitation. The tragedy and trauma which Sidhwa has highlighted through characterization of Hamida and Ayah insinuate that women did not belong to religious or national ideologies of the divide. Hamida and Ayah are dislocated, molested and abducted by their enemies but they are not certain about their acceptability by their own male family members because they have been dishonored. Imposed alienation and enforced detachment of women from their families epitomize the politics of partition. Women in post-partition era are depicted through Hamida and Ayah; cohorts of fallen women lamenting in the jails for their loved ones and for their sexual assault. 
Their agony can never be satiated - their mourning will never end. While evaluating the social positioning of Pakistani women Farida Shaheed (1991) contextualizes the establishment of tribal and feudal systems of Pakistan in colonial suzrain:

To control and administer large territories under their rule, without deploying large numbers of British, the British Raj strengthened the feudal and/or tribal system in the rural areas by making land alienable and granting feudal and tribal leaders absolute ownership [power]. In turn this increased the over-all hold of the feudal ideology in the rural areas, which incorporated the most rigid forms of purdah and the social control of women (Shaheed, 1991, p.152).

After the departure of British colonizers, indigenous women of Pakistan further subordinated by the neocolonial masters through feudal and tribal infrastructure. The praxis of feudalism which is negated as an institutionalized exploitation in its own locality however assumed as strategic human development model for its colonies. This infrastructure cast dual marginalization over Pakistani women. Muhammad Asim Siddiqui (2011) notes, that nearly all Pakistani fiction writers have dealt with the "feudal class" in their writings, he continues to elaborate that "feudal class also knows how to use religion to its advantage, even when religion does not have a very strong basis in the lives of people it has been used by the feudal class to maintain its power and position" (Siddiqui, 2011, p.186). Tehmina Durrani's autobiographical narrative My Feudal Lord (1994) depicts her despondent marital life with Mr. Ghulam Mustafa Khar; a feudal lord and a politician. Her name occupies distinguished place in the rags of Pakistani literature for articulating the oppressive silences of women whose existence is impregnate with socio-cultural jargons of good and bad, acceptable and unacceptable, dignified or disgraced. Through implementation of sporadic religious prescriptions, Durrani prodigiously represents the predicaments of Pakistani women which cease the possibilities of their resistance against the hierarchical social construction. During the course of novel, she displays her gradual liberation from the indurate tyranny of an inoperable feudal lord, who casts every possible emotional, psychological and physical abuse on her during their relationship Durrani states, "Pakistani woman will endure almost anything in order to hold a marriage together. In our society, marriage may be purgatory, but divorce is hell" (1994, p. 77). Valiance depiction of male chauvinism and its remonstration in Durrani's narrative, articulates the intricate exigencies of women from which they cannot liberate themselves. She reiterates the insignificance of women "[a]ccording to feudal tradition, wife was honor-bound to live her life according to her husband's whims. Woman was like a man's land" (1994, p. 107). Durrani's oppressions disclose women predicaments holistically attributed to their existence devoid of their socio-economic strata. Woman as honour-bound to her parents before marriage and then later to her husband substantiates her as object to be possessed or dispossessed through marriage contract. Durrani's physical assault in London at her parents' apartment further strengthens the image of women as property of their male counterparts, where Mustafa 
not merely victimizes Durrani but also seduces Adila; Durrani's sister. While concealing her bruises she continues to pretend as a devoted wife:

It was schizophrenic existence. The humiliation of not being able to keep my husband happy and of falling short of my mother's definition of the ideal wife was becoming more frightening than the beatings---It simply affirmed my inadequacy (1994, p. 131).

Continuous assault instigates Durrani to rebuff Mustafa: "[t]his is my father's house and I do not think that you should dare to lift your hand on me here!" (1994, p. 134). However, her resistance becomes feeble when she is reminded by her father that she can "only leave his home in a coffin" (Durrani, 1994, p. 126). In the absence of family support Durrani portrays the degree of helplessness and vulnerability of a married woman who experiences alienation and outcast from her family in case of retaliation against her oppression. Revelation of Mustufa's lubricious relationship with Adila devastates Durrani, and in order to avoid degradation of their loveless married life she blames Adila for promiscuity. However, being battered by the butt of his shotgun, Durrani implodes and thinks of separation as the only solution to manifest her agency: "[s]ilence condones injustice, breeds subservience and fosters a malignant hypocrisy....feudal lords thrive and multiply on silence. Muslim women must learn to raise their voices against injustice" (1994, p. 375). Durrani's womanhood and self esteem serve as stimulation to escape the social as well as familial constraints of marginalization and objectification. Her silences validate social exclusion for which rediscovering her marginalized self appears to be the ultimate panacea for all exploited and dispossessed women. As Durrani highlights in an interview:

My works are about breaking a silence for a part of society which cannot speak out. I am called bold because these are issues one does not talk about one's own life. I suppose my passion for reform is overwhelming and I think when anything overwhelmed you that much you have a natural boldness because you step out of the realm of fear (Ali, 2003).

This valor is conspicuous in Pakistani fiction to articulate women's agency and resistance against the propriety of socio-cultural infrastructures. Durrani's transformation from subjugation to emancipation also takes place in Uzma Aslam's female characters though the mode of manifestation is entirely different. Trespassing (2003), short-listed for the Commonwealth Writers Prize in 2003, Khan's novel explores themes of freedom and betrayal across two generations. Uzma Aslam's creation of female characters in Trespassing (2003) is a manifestation of self determination and emancipation of womanhood. Riffat is an innovative character who runs her family's silk business with an exploration of indigenous silk production by resisting the patriarchal social infrastructure where women is objectified by appeasement to the male supremacy. She raises her daughter Dia with independent thinking abilities and sets her free to determine a path for her life. Dia relays that "[t]he best thing about her mother was that she never tried to make Dia more like herself" (2003, p. 193). Dia reinstates her marriage priorities before 
her friend with an emphasis on love instead of preferring marriage for social standing. Through the character of Dia, Khan supplies an epitome of self determination which appears to be difficult in oscillating societal conditions. The female characterization in Trespassing exposits fluctuating social standing in the society that destabilizes nomenclature of determinism, agency into dormant ineptness and belligerent helplessness:

There was an unspoken agreement between men: Woman was not a topic worth mentioning, unless she aroused them sexually. But man was a topic women devoured from every angle. Dia was certain this was the most obvious yet neglected reason for their disparate positions in society: time. Women spent it on men. Men spent it on men (Khan, 2003, p. 94).

Anu, in comparison, lives a life determinedly and devotedly in subservience to her cultural norms and ethics. Her cultural propensity is visible through her life patterns: she was fundamentally awkward in high society. She had not been born into it... She was twenty-three, married at sixteen, educated only till class nine, clever enough to understand English but could speak it with an accent that was hateful to her in English speaking company (Khan, 2003, p. 15). Anu's conformity to her patriarchal rituals and her deliberate escape from American styling illustrates her agency that she displays by celebrating her existence in the domestic sphere. Khan seemingly suggests Anu's potential even to retaliate against the patriarchal norms if that repeal her agency. The decision of getting marrying with Mansoor strengthened social stability for Riffat. The author's description of different ends of both ladies insists on woman's liberation and emancipation in private and public spheres of life: 'Karachi's becoming a city of entrepreneurial Mothers. They get what they want. They just have to give in first. It's simple mechanics' (Khan, 2003, p.114). Riffat appears to be a character who is creative, decisive and liberal. Her deliberate affair with Shafqat after her marriage intends to break the set standards of loyalty that are only associated with female figure. The woman within the bonds of marriage is associated with superhuman qualities, as Beauvoir (1952) states, "the 'virtuous woman' of proverbs, the 'perfect mother', the 'honest woman', and so on. This is why many wives let themselves go, they are being themselves only in the absence of their husbands" (1952, p. 474). Beauvoir argues that wife is regarded as an object of physical gratification for her husband while her erotic life is suppressed in the process of reproduction (1952, p. 436). The suppression of erotic desires leads woman to resist the social configurations of faithfulness and loyalty, consequently, she finds different rooms of escape. Trespassing of Riffat and Shafqat, which eventually captivates Dia and Daanish to its disastrous ends, demonstrates Riffat's experimentation with the negotiations of her emotional self. Riffat's illicit liaison against the implicit decrees of Pakistani society consequently produces tragic ends for her daughter that manifests their inability to change the constructed frame of the culture. Framing the tragedy of Riffat and Dia, Khan reiterates the impervious cultural allegations to proclaim "TRESPASSERS WILL BE PROSECUTED” (Khan, 2003, p. 373). 


\section{Conclusions}

Women marginalization is a social dilemma but due to the introvert exploitations women rebuff alone and lose their familial ties consequently. There is a need to articulate the similarities of victimization and strategic resistance to assert their selfhood. Pakistani fiction portrays indigenous woman as an object of patriarchal construct whereby she submits herself to her male owner whatever the condition may be. But female characters are portrayed in the selected fiction resists the patriarchal exploitation and victimization in their own ways that better suit the situations. Through female characterization the women writers organize specific academic movement of awakening that provides situational analysis to relate with the turbulences of the fictional world to correspond the real challenges. This establishes an alliance between the scattered oppressions as well as scattered resistance to form a collective reprisal against homogenous patriarchal propriety. The fiction exposes the troubles and problems of indigenous women at individual level and attempts to resolve their problems by engaging them in various states of affair.

\section{References}

Ahmed, Z. (2009). Pakistani Feminist Fiction and the Empowerment of Women. Pakistaniaat: A Journal of Pakistan Studies, vol.1:2, pp.90-102.

Ali, Rabia. U. (2009). Muslim Women and the Partition of India: A Historiographical Silence. Islamic Studies, vol.48:3, pp.425-436.

Ali, S. (2003). Out of the Realm of Fear. Verve Online Archive (4).

Bahri, D. (1999). Telling Tales. Interventions , 1 (2), 217-234.

Beauvoir, S. D. (1952). The Second Sex. New York : Knopf.

Butalia, U. (1998). The Other Side of Silence: Voices From the Partition of India. New Delhi: Penguin Books.

Child Marriage Restraint Act. (1929).

Cilano, C. (2009). 'Writing from Extreme Edges': Pakistani English-Language Fiction. ARIEL , 183-201.

Datta, A. B. (2006). Gendering Oral History of Partition: Interrogating Patriarchy. Economic and Political Weekly, vol.41:5, pp.2229-2235. 
Didur, J. (1998). Cracking the Nation: Gender, Minorities and Agency in Bapsi Sidhwa's Cracking India. ARIEL: A Review of International English Literature, vol.29:3, pp.43-64.

Dissolution of Muslim Marriages Act. (1939).

Durrani, T. (1994). My Fuedal Lord. Great Britain: Bantam Press.

Gardezi, F. (2008). Islam, feminism and the Women's Movement in Pakistan: 1981-1991. In P. Banerjee, Women in Peace Politics (pp. 97-111). California: SAGE publications inc.

Haqqani, H. (2005). Pakistan: Between Mosque and Military. Washington DC: The Bookings Institution Press.

Hashmi, A. (1990). Poetry, Pakistani Idiom in English, and the Groupies. World Literature Today, vol.64:2, pp.268-271.

Indian Evidence Act. (1872).

Kandiyoti, D. (1988). Bargaining with Patriarchy. Gender \& Society, vol.2:3, pp.274-290.

Khan, N. S. (2000). The Women's Movement Revisted: Areas of concern for the Future.

Khan, U. A. (2003). Trespassing. New York: Metropolitan Books.

Mohanty, C. T. (2003). Feminism Without Borders: Decolonising Theory, Practicing Solidarity. USA: Duke University Press.

Musarrat, P. D. (2013). Protection of Women Rights Through Legal Reforms in Pakistan. Journal of Public Administration and Governance, 119-142.

Nawaz, M. S. (1990). The Heart Divided. Lahore: A. S. R. Publications.

Naz, D. A. (2013). A Paradigm Shift in Women's Movement and Gender Reforms in Pakistan. Global Journal of Human Science Sociology and Culture , 20-26.

Pandey, M. (2003). Feminism in contemporary British and Indian Fiction. Delhi: Sarup and Sons.

Rahman, T. (1991). A History of Pakistani Literature in English. Lahore: Vanguard. 
Sa'ar, A. (2005). Postcolonial Feminism, the Politics of Identification, and the Liberal Bargain. Gender \& Society, vol.19:05, pp.680-700.

Shaheed, K. M. (1987). Women of Pakistan: Two Steps Forward, One Step Back . London New Jersey: Zed Books limited.

Shami, M. A. (2010). Political Empowerment of Women in Pakistan. Journal of Pakistan Vision, vol.10:1, pp.141-150.

Shamsie, M. (2005). And The World Changed: Contemporary Stories by Pakistani Women. New Delhi: Women Unlimited.

Shamsie, M. (2006). Introduction. In M. Shamsie (Ed.), And the World Changed Contemporary Stories by Pakistani Women (pp. xi-xx). New York: Oxford University Press.

Shamsie, M. (2011). Introduction: Duality and diversity in Pakistani English Literature. Journal of Postcolonial Writing, vol.47:2, pp.119-121.

Sidhwa, B. (1988). Ice Candy Man. New Delhi: Penguin Books.

Siddiqui, A. M. (2011). The Political or the Social?: Qaisra Shahraz and the Present Pakistani Writings in English. In A. a. Kidwai (Ed.), The Holy and the Unholy: Critical Essays on Qaisra Shahraz's Fiction (pp. 183-204). New Delh: Sarup Book Publishers.

Spivak, G. C. (2003). Can the Subaltern Speak? In G. G. Bill Ashcroft (Ed.), Postcolonial Studies Reader (pp. 24-28). New York: Routledge.

The Constitution of Pakistan, 1956 Article, 17 (1).

Young, R. C. (2005). Postcolonialism. Karachi: Oxford University Press.

Zia, A. S. (2010). A Policy Framework for Women's Equal Rights. Islamabad: National Commision on the Status of Women (NCSW).

Sadaf Mehmood is Teaching / Research Associate in the Department of English, International Islamic University, Islamabad. 